Published in final edited form as:

Angew Chem Int Ed Engl. 2019 May 20; 58(21): 6967-6971. doi:10.1002/anie.201902009.

\title{
A Stable, Non-corrosive Perfluorinated Pinacolatoborate Mg Electrolyte for Rechargeable Mg Batteries
}

\author{
Jian Luo ${ }^{\dagger}$, Yujing $\mathrm{Bi}^{\dagger}$, Liping Zhang, Xiaoyin Zhang, T. Leo Liu* \\ The Department of Chemistry and Biochemistry, Utah State University, Logan, UT
}

\section{Abstract}

$\mathrm{Mg}$ batteries are a promising energy storage system because of physicochemical merits of $\mathrm{Mg}$ metal as an anode material. However, the lack of electrochemically and chemically stable magnesium electrolytes impedes the development of $\mathrm{Mg}$ batteries. In this study, a newly designed chloride-free magnesium fluorinated pinacolatoborate, $\mathrm{Mg}\left[\mathrm{B}\left(\left(\mathrm{CF}_{3}\right)_{4} \mathrm{C}_{2} \mathrm{O}_{2}\right)_{2}\right]_{2}$ (abbreviated as $\mathbf{M g}$ FPB), was synthesized by convenient methods from commercially available reagents and fully characterized. The Mg-FPB electrolyte delivered outstanding electrochemical performance, specifically, 95\% coulombic efficiency and $197 \mathrm{mV}$ overpotential for reversible $\mathrm{Mg}$ deposition, and anodic stability up to $4.0 \mathrm{~V}$ vs $\mathrm{Mg}$. The $\mathbf{M g}$-FPB electrolyte was applied to demonstrate a high voltage rechargeable $\mathrm{Mg} / \mathrm{MnO}_{2}$ battery with a discharge capacity of $150 \mathrm{mAh} / \mathrm{g}$.

\section{Graphical Abstract}

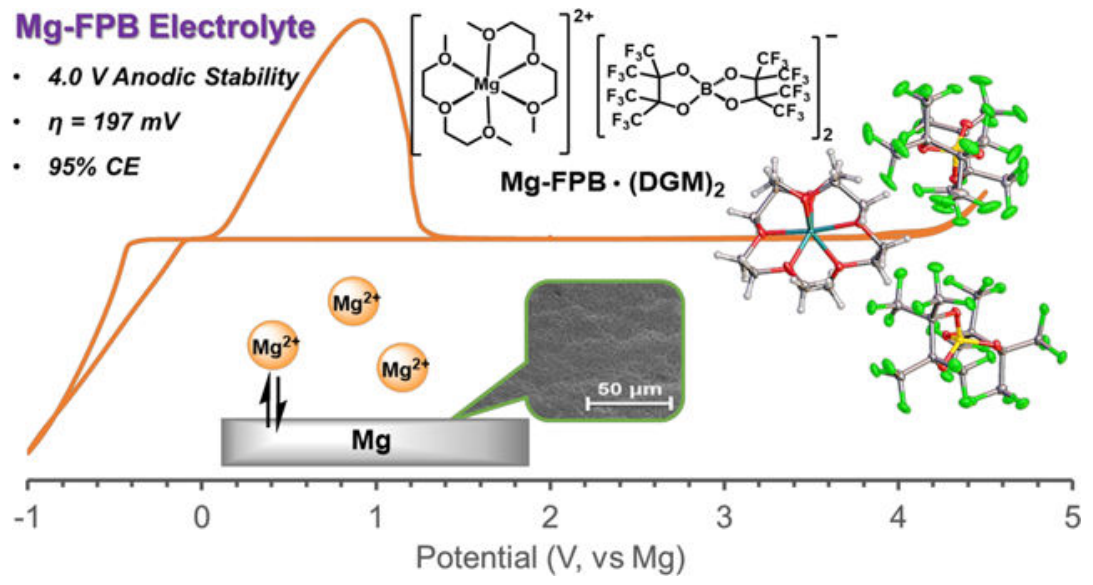

\section{Keywords}

Magnesium electrolytes; perfluorinated pinacolatoborate; Mg battery; energy storage

\footnotetext{
*Corresponding Author: Leo.Liu@usu.edu.

$\dagger$ These authors contributed equally.
}

Supporting Information. The Supporting Information is available free of charge on the ACS Publications website. Experimental procedures, post-cell NMR and CV analysis, cell impedance spectroscopy, battery data. 
Electrification of modern society including portable devices, electrical vehicles, and gridscale storage has driven intensive research development of inexpensive, safe, long-cycling life, high performance energy storage technologies. ${ }^{1}$ Recently, a great deal of effort has been focused on developing low costs and high energy density rechargeable batteries beyond $\mathrm{Li}$ ion batteries using abundant alkaline or alkaline earth metals as anode materials. Magnesium $(\mathrm{Mg})$ batteries are a promising electrochemical energy storage system because of their attractive technological merits: being safe (mild reactivity), environmentally benign, inexpensive (ca. 24 times cheaper than Li), high capacity (2205 Ah/kg or $3832 \mathrm{Ah} / \mathrm{L}$ vs 3861 $\mathrm{Ah} / \mathrm{kg}$ or $2062 \mathrm{Ah} / \mathrm{L}$ for $\mathrm{Li}$ ), and high reduction potential (-2.37 vs SHE) ${ }^{2-4}$ However, the research of rechargeable $\mathrm{Mg}$ batteries is still in the infancy stage, and their development are primarily hampered by two great challenges, the lacks of high performance $\mathrm{Mg}^{2+}$ electrolyte $^{3-4}$ and energy-dense cathode materials. ${ }^{2}$

$\mathrm{As}^{2+} \mathrm{Mg}^{2+}$ electrolytes play a pivotal role in rechargeable $\mathrm{Mg}$ batteries, intensive efforts have been made in developing high-performance $\mathrm{Mg}^{2+}$ electrolytes in the past decade. ${ }^{5-13}$ The reported $\mathrm{Mg}^{2+}$ electrolytes applied in $\mathrm{Mg}$ batteries are mainly based on the combination of a magnesium containing Lewis base (e.g. Grignard reagents and $\mathrm{MgCl}_{2}$ ) and a Lewis acid (e.g. $\mathrm{AlCl} 3$ and $\mathrm{AlPh} 3$ ), known as $\mathrm{Mg}$-chloride complex electrolytes as their active species are characteristic of $\mathrm{Mg}-\mathrm{Cl}$ coordination moieties. ${ }^{3-4}$ The most well-known Mg-chloride complex electrolytes contains $\left[(\mu-\mathrm{Cl})_{3} \mathrm{Mg}_{2}(\mathrm{THF})_{6}\right]^{+}$dimer mono-cation as active species. ${ }^{4}$ However, chlorides contained in $\mathrm{Mg}$-chloride complex electrolytes are corrosive and not chemically compatible with high voltage cathode materials and/or common current collectors (e.g. stainless steel or Al). ${ }^{3-4}$ Thus, developing stable and simple $\mathrm{Mg}^{2+}$ salts free of chloride like those used in $\mathrm{Li}$ ion batteries is of great need but remains extremely challenging. ${ }^{4}$ There are a few rare examples of $\mathrm{Cl}$-free $\mathrm{Mg}$ salt electrolytes reported for reversible $\mathrm{Mg}$ deposition while achieving high anodic stability (up to $4.0 \mathrm{~V}$ vs $\mathrm{Mg}$ ), including $\mathrm{Mg}\left(\mathrm{CB}_{11} \mathrm{H}_{12}\right)_{2},{ }^{14-15} \mathrm{Mg}\left(\mathrm{CB}_{11} \mathrm{H}_{11} \mathrm{~F}\right)_{2},{ }^{16} \mathrm{Mg}\left[\mathrm{Al}(\mathrm{HFIP})_{4}\right]_{2},{ }^{17}$ and $\mathrm{Mg}\left[\mathrm{B}(\mathrm{HFIP})_{4}\right]_{2}$ $\left(\mathrm{HFIP}=-\mathrm{OCH}\left(\mathrm{CF}_{3}\right)_{2}\right) \cdot{ }^{18-19}$ However, $\mathrm{Mg}\left(\mathrm{CB}_{11} \mathrm{H}_{12}\right)_{2}$ is expensive and not suitable for broad $\mathrm{Mg}$ battery applications because the synthesis of carborane anion $\left(\mathrm{CB}_{11} \mathrm{H}_{12}{ }^{-}\right)$ containing precursors are not trivial and they are very pricy with very limited commercial availability. And $\mathrm{Mg}\left[\mathrm{B}(\mathrm{HFIP})_{4}\right]_{2}$ lacks of good chemical stability at ambient conditions as it undergoes chemical decomposition with moisture, ${ }^{18}$ which is believed same as $\mathrm{Mg}\left[\mathrm{Al}(\mathrm{HFIP})_{4}\right]_{2}$. Therefore, it is highly demanding to develop new $\mathrm{Cl}$-free $\mathrm{Mg}$ electrolytes from inexpensive commercially available chemicals to deliver high electrochemical performance and excellent chemical stability simultaneously. Herein, we report highly electrochemically active, anodically stable, and non-corrosive magnesium fluorinated pinacolatoborate, $\mathrm{Mg}\left[\mathrm{B}\left(\left(\mathrm{CF}_{3}\right)_{4} \mathrm{C}_{2} \mathrm{O}_{2}\right)_{2}\right]_{2}$ (abbreviated as Mg-FPB, Figure 1), which is featured with strongly coordinating perfluorinated pinacolatoborate bidendate ligands to stabilize the boron center. The Mg-FPB electrolyte delivered outstanding electrochemical performance, specifically, 95\% coulombic efficiency and $197 \mathrm{mV}$ overpotential for reversible $\mathrm{Mg}$ deposition, and anodic stability up to $4.0 \mathrm{~V}$ vs $\mathrm{Mg}$. In addition, the $\mathbf{M g}$-FPB electrolyte was applied to demonstrate a $2.0 \mathrm{~V}$ high voltage $\mathrm{Mg} / \mathrm{MnO}_{2}$ battery.

To develop Cl-free $\mathrm{Mg}$ salt electrolytes, a key consideration is the choice of the weakly coordinating anions because they need to be electrochemical and chemically stable to enable 
wide voltage window and electrochemical/chemical compatibility with electrode materials. ${ }^{3}$ In addition, $\mathrm{Mg}$ salts with weaker anion-cation interaction give higher solubility and ionic conductivity in their electrolyte solutions. ${ }^{14,} 16$ In light of strong B-O bonds $(809 \mathrm{~kJ} /$ $\mathrm{mol})^{7,20}$ and the chelating effect of polydentate ligands, we have sought to employ chemically stable B anions supported with bidentate alkyloxide ligands in developing Clfree $\mathrm{Mg}$ salt electrolytes. We first attempted the idea by reacting $\mathrm{Mg}\left(\mathrm{BH}_{4}\right)_{2}$ with pinacol (hexafluoro-2,3-dime-thyl-2,3-butanediol). However, the reaction could not go completion to form magnesium bispinacolato borate, $\mathrm{Mg}\left[\mathrm{B}\left(\left(\mathrm{CH}_{3}\right)_{4} \mathrm{C}_{2} \mathrm{O}_{2}\right)_{2}\right]_{2}$. Because of a high $\mathrm{pKa}$ (ca. 18) of the alcohol protons of pinacol, NMR studies indicate that pinacol only undergoes partly deprotonation by $\mathrm{BH}_{4}^{-}$even in refluxed DME (Figure $\mathrm{S} 1$ ). In addition, the resulting solution is not electrochemically active for $\mathrm{Mg}$ deposition (Figure S1).

We then used a perfluorinated pinacol, (hexafluoro-2,3-ditrifluoromethyl-2,3-butanediol), as a bidentate alkyloxide ligand precursor. Due to the strong electron-withdrawing effect of $\mathrm{CF}_{3}$ groups, the perfluorinated pinacol is expected to have more acidic protons to proceed complete deprotonation with $\mathrm{BH}_{4}{ }^{-}$. The reaction of 1:4 ratio of $\mathrm{Mg}\left(\mathrm{BH}_{4}\right)_{2}$ and the perfluorinated pinacol readily proceeded to completion at $60{ }^{\circ} \mathrm{C}$ in DME to yield magnesium fluorinated pinacolatoborate, $\mathrm{Mg}\left[\mathrm{B}\left(\left(\mathrm{CF}_{3}\right)_{4} \mathrm{C}_{2} \mathrm{O}_{2}\right)_{2}\right]_{2}$ (abbreviated as Mg-FPB) in a good isolated yield of $87 \%$ (Figure $1 \mathrm{~A}$ ). Mg-FPB salt was fully characterized by ${ }^{11} \mathrm{~B}$ NMR, ${ }^{19} \mathrm{~F}-\mathrm{NMR}$, and elemental analysis. Mg-FPB displays a single resonance in the ${ }^{19} \mathrm{~F}$ NMR (70.36 ppm) and ${ }^{11} \mathrm{~B}-\mathrm{NMR}(111.36 \mathrm{ppm})$ spectra (Figure 1B and 1C), which is consistent with the expected tetrahedral geometry of the FPB anion. It was found that the Mg-FPB salt has a good solubility of $0.5 \mathrm{M}$ in diglyme (DGM). The molecular structure of Mg-FPB solvated by DGM was unambiguously determined by single crystal X-ray diffraction (Figure 1D). In the X-ray diffraction determined structure, the $\mathrm{Mg}$ ion is coordinated by two tridendate DGM in an octahedral geometry and paired with two tetrahedral FPB anions for charge neutrality.

A $0.5 \mathrm{M}$ Mg-FPB electrolyte in DGM (3.95 mS/cm conductivity) was subsequently studied for its electrochemical activity for $\mathrm{Mg}$ deposition/stripping. As shown in the cyclic voltammogram (Figure 2A), the Mg-FPB electrolyte displayed a reversible Mg deposition/ stripping wave with an onset potential at $-0.308 \mathrm{~V}$ vs $\mathrm{Mg}$ and a stripping potential at -0.111 $\mathrm{V}$, giving overpotential of $197 \mathrm{mV}$ which is comparable with MMAC electrolytes ${ }^{10}$ but smaller than reported Cl-free $\mathrm{Mg}$ electrolytes. ${ }^{14-19}$ A high coulombic efficiency of $95 \%$ was obtained at $50 \mathrm{mV} / \mathrm{s}$ with glassy carbon electrode (Figure S2). Furthermore, the Mg-FPB electrolyte exhibited an outstanding anodic stability at $>4.0 \mathrm{~V} \mathrm{vs} \mathrm{Mg}$, which is comparable with reported $\mathrm{Cl}$-free $\mathrm{Mg}$ electrolytes, ${ }^{14-19}$ but significantly improved over other reported Mg electrolytes. ${ }^{4}$

Chloride contained $\mathrm{Mg}$ electrolytes are corrosive with common metallic current collectors, such as stainless steel (SS) and aluminum (Al), which makes them not practically attractive. ${ }^{4}$ In a stark contrast, the Mg-FPB electrolyte displayed high anodic stability of ca. $4.0 \mathrm{~V}$ vs $\mathrm{Mg}$ with a variety of working electrodes including stainless steel (SS), Ti, and $\mathrm{Al}$ (Figure 2B). All of them demonstrated reversible Mg deposition with coulombic efficiencies of $81 \%$ for $\mathrm{SS}, 83 \% \mathrm{Ti}$, and $95 \%$ for $\mathrm{Al}$, respectively (Figure S3). In addition, when Mg metal was 
used as a working electrode, as shown in Figure S3D, the Mg plating/stripping on the surface of Mg metal was extremely smooth, as no overpotential was observed.

Subsequently, a symmetric $\mathrm{Mg}|0.5 \mathrm{M} \mathrm{Mg}-\mathrm{FPB}| \mathrm{Mg}$ cell was assembled to evaluate the longterm electrochemical performance of the Mg-FPB electrolyte as shown in Figure 3A and 3B. The symmetric cell was tested from $50 \mu \mathrm{A} / \mathrm{cm}^{2}$ to $1.0 \mathrm{~mA} / \mathrm{cm}^{2}$ current density. At 50 $\mu \mathrm{A} / \mathrm{cm}^{2}$ current density, the polarization is lowered to $70 \mathrm{mV}$ (vs. $\mathrm{Mg}$ ), even the current density was increased to $1.0 \mathrm{~mA} / \mathrm{cm}^{2}$, the polarization is still below $100 \mathrm{mV}$ (ca. $90 \mathrm{mV}$ vs. $\mathrm{Mg}$ ). The high rate performance of the Mg-FPB electrolyte is attributed to the designed noncoordinating FPB anion that has weak interaction with $\mathrm{Mg}^{2+}$ cation and enable fast electrochemical deposition and striping process. The symmetric cell was further cycled at $0.1 \mathrm{~mA} / \mathrm{cm}^{2}$ for 500 hours, and demonstrated highly stable polarization (Figure 3B). The stable polarization during galvanostatic cycling demonstrates that, benefitted from the stable FPB anion, the MgFPB electrolyte has an excellent cathodic stability.

To investigate the beneficial effects of the chelating FPB ligand in the Mg-FPB over the monodendate ligand used in the reported $\mathrm{Mg}\left[\mathrm{B}(\mathrm{HFIP})_{4}\right]_{2}$ electrolyte, ${ }^{18}$ we also conducted $\mathrm{CV}$ studies of $\mathrm{Mg}\left[\mathrm{B}(\mathrm{HFIP})_{4}\right]_{2}$ under the same conditions (Figure $\mathrm{S} 2$ ). It was found that $\mathrm{Mg}\left[\mathrm{B}(\mathrm{HFIP})_{4}\right]_{2}$ displayed a larger overpotential $(267 \mathrm{mV})$ and lower coulombic efficiency (83\%) for Mg deposition/stripping than Mg-FPB although comparable cathodic stability (see Table 1). The Mg deposition/stripping reversibility of the Mg-FPB electrolyte is much better than that of $\mathrm{Mg}\left[\mathrm{B}(\mathrm{HFIP})_{4}\right]_{2}$ (Figure S2 and S4). Furthermore, in the symmetric cell studies, the $\mathrm{Mg}\left[\mathrm{B}(\mathrm{HFIP})_{4}\right]_{2}$ electrolyte manifested much higher overpotential (Figure S5 and S6), which is consistent with the literature. ${ }^{18}$ The $\mathrm{Mg}\left[\mathrm{B}(\mathrm{HFIP})_{4}\right]_{2}$ electrolyte took ca. 150 hours to reach comparable overpotential as Mg-FPB. In the bulky electrochemical Mg deposition studies, both Mg-FPB and $\mathrm{Mg}\left[\mathrm{B}(\mathrm{HFIP})_{4}\right]_{2}$ electrolytes yielded a smooth and dendrite free $\mathrm{Mg}$ layer (Figure S7). However, in the EDX spectrum of $\mathrm{Mg}$ layer deposited from $\mathrm{Mg}\left[\mathrm{B}(\mathrm{HFIP})_{4}\right]_{2}$, there were $12.5 \% \mathrm{C}, 9.9 \% \mathrm{O}$, and $1.9 \% \mathrm{~F}$ elements. The observation indicates the electrochemical decomposition of the $\left[\mathrm{B}(\mathrm{HFIP})_{4}\right]^{-}$anion during the Mg plating process. In contrast, the EDX spectrum of Mg layer deposited from MgFPB electrolyte was very clean, only $\mathrm{Mg}$ metal was observed.

In addition, the chemical stability of the Mg-FPB and $\mathrm{Mg}\left[\mathrm{B}(\mathrm{HFIP})_{4}\right]_{2}$ electrolytes was further compared by exposure to moisture (1\% water added). As shown in Figure S8, the Mg-FPB electrolyte remained a clean solution after water treatment for two days, and its ${ }^{19}$ F-NMR spectrum remained unchanged, which indicated the high chemical stability of FPB anion against hydrolysis. However, the $\mathrm{Mg}\left[\mathrm{B}(\mathrm{HFIP})_{4}\right]_{2}$ electrolyte was changed from clean solution to a white gel. A new signal at $-76.45 \mathrm{ppm}$ chemical shift was observed in the ${ }^{19} \mathrm{~F}-\mathrm{NMR}$ spectrum which clearly indicated the decomposition of the $\left[\mathrm{B}(\mathrm{HFIP})_{4}\right]^{-}$anion. The observed superior electrochemical and chemical stability of Mg-FPB over $\mathrm{Mg}\left[\mathrm{B}(\mathrm{HFIP})_{4}\right]_{2}$ is attributed to the stabilization effect of the perfluorinated pinacolato bidentate ligand. In addition, albeit subject to further mechanistic studies, we hypothesize that acidic proton in the alpha carbon of the HFIP substituent may be also responsible to the inferior performance of the $\mathrm{Mg}\left[\mathrm{B}(\mathrm{HFIP})_{4}\right]_{2}$ electrolyte. 
Finally, we conducted preliminary studies of an $\mathrm{Mg} / \mathrm{MnO}_{2}$ battery to further demonstrate the anodic stability of the Mg-FPB electrolyte in Mg ion batteries. Due to the high anodic stability of the Mg-FPB electrolyte ( $>4.0 \mathrm{~V}$ vs. $\mathrm{Mg}$ ), the $\mathrm{Mg} / \mathrm{MnO}_{2}$ battery was charged up to $3.9 \mathrm{~V}$ as shown in Figure 4 (green curves). The $\mathrm{Mg} / \mathrm{MnO}_{2} \mathrm{Mg}$ ion battery delivered $2.0 \mathrm{~V}$ battery voltage and $150 \mathrm{mAh} / \mathrm{g}$ discharge capacity at a current density of $10 \mu \mathrm{A} / \mathrm{g}$. However, the $\mathrm{Mg} / \mathrm{MnO}_{2}$ battery using chlorides containing MMAC electrolyte was constantly charged at $1.1 \mathrm{~V}$ due to the lower anodic stability and corrosion of electrolyte to the SS current collector while delivering a negligible discharge capacity (Figure 4, red curves).

It is worth noting that, as the FPB counter anion delivers excellent chemical and electrochemical stabilities, the FPB-based alkaline or alkaline earth metal salts, including LiFPB, Na-FPB, K-FPB, and Ca-FPB, were also prepared similarly. Li-FPB has demonstrated promising metal deposition electrochemistry in preliminary studies (Figure S10). These salts were expected to have broad applications in energy storage and other fields.

In conclusion, a new $\mathrm{Cl}$-free $\mathrm{Mg}$ electrolyte with non-coordinating perfluorinated pinacolatoborate counter anions was developed and comprehensively studied by NMR, single crystal x-ray diffraction, and electrochemical studies. The Mg-FPB electrolyte exhibited outstanding electrochemical performance for Mg plating/stripping with overpotential of $197 \mathrm{mV}$, a coulombic efficiency of $95 \%$, and anodic stability above $4.0 \mathrm{~V}$ with a variety of current collectors. It is believed that the Mg-FPB electrolyte with its excellent chemical and electrochemical stabilities will find broad applications in $\mathrm{Mg}$ batteries. In addition, the molecular design of Mg-FPB electrolyte with the emphasis of the highly stable perfluorinated chelating ligands for the counter anion will inspire the development of new electrolytes not limited to $\mathrm{Mg}^{2+}$ ion.

\section{Supplementary Material}

Refer to Web version on PubMed Central for supplementary material.

\section{ACKNOWLEDGMENT}

We thank the financial support for this research from National Science Foundation Career Award, faculty startup funds from Utah State University and the Utah Science Technology and Research initiative (USTAR) UTAG award.

\section{REFERENCES:}

1. Dunn B; Kamath H; Tarascon J-M, Electrical Energy Storage for the Grid: A Battery of Choices. Science 2011, 334 (6058), 928-935. [PubMed: 22096188]

2. Canepa P; Sai Gautam G; Hannah DC; Malik R; Liu M; Gallagher KG; Persson KA; Ceder G, Odyssey of Multivalent Cathode Materials: Open Questions and Future Challenges. Chem. Rev 2017, 117 (5), 4287-4341. [PubMed: 28269988]

3. Xu K, Electrolytes and Interphases in Li-Ion Batteries and Beyond. Chem. Rev 2014, 114 (23), 11503-11618. [PubMed: 25351820]

4. He S; Nielson KV; Luo J; Liu TL, Recent advances on $\mathrm{MgCl}_{2}$ based electrolytes for rechargeable Mg batteries. Energy Stor. Mater 2017, 8, 184-188.

5. Pour N; Gofer Y; Major DT; Aurbach D, Structural Analysis of Electrolyte Solutions for Rechargeable Mg Batteries by Stereoscopic Means and DFT Calculations. J. Am. Chem. Soc 2011, 133 (16), 6270-6278. [PubMed: 21456525] 
6. Kim HS; Arthur TS; Allred GD; Zajicek J; Newman JG; Rodnyansky AE; Oliver AG; Boggess WC; Muldoon J, Structure and compatibility of a magnesium electrolyte with a sulphur cathode. Nat. Commun 2011, 2, 427. [PubMed: 21829189]

7. Guo Y.-s.; Zhang F; Yang J; Wang F.-f.; NuLi Y; Hirano S.-i., Boron-based electrolyte solutions with wide electrochemical windows for rechargeable magnesium batteries. Energy Environ. Sci 2012, 5 (10), 9100-9106.

8. Doe RE; Han R; Hwang J; Gmitter AJ; Shterenberg I; Yoo HD; Pour N; Aurbach D, Novel, Electrolyte Solutions Comprising Fully Inorganic Salts with High Anodic Stability for Rechargeable Magnesium Batteries. Chem. Commun 2014, 50 (2), 243-245.

9. Liu T; Shao Y; Li G; Gu M; Hu J; Xu S; Nie Z; Chen X; Wang C; Liu J, A facile approach using $\mathrm{MgCl} 2$ to formulate high performance $\mathrm{Mg} 2+$ electrolytes for rechargeable $\mathrm{Mg}$ batteries. J. Mater. Chem. A 2014, 2 (10), 3430-3438.

10. Luo J; He S; Liu TL, Tertiary Mg/MgCl2/AlCl3 Inorganic Mg2+ Electrolytes with Unprecedented Electrochemical Performance for Reversible Mg Deposition. ACS Energy Lett 2017, 2 (5), 11971202.

11. Watkins T; Kumar A; Buttry DA, Designer Ionic Liquids for Reversible Electrochemical Deposition/Dissolution of Magnesium. J. Am. Chem. Soc 2016, 138 (2), 641-650. [PubMed: 26683518]

12. Pan B; Zhang J; Huang J; Vaughey JT; Zhang L; Han S-D; Burrell AK; Zhang Z; Liao C, A Lewis acid-free and phenolate-based magnesium electrolyte for rechargeable magnesium batteries. Chem. Commun 2015, 51 (28), 6214-6217.

13. See KA; Chapman KW; Zhu L; Wiaderek KM; Borkiewicz OJ; Barile CJ; Chupas PJ; Gewirth AA, The Interplay of $\mathrm{Al}$ and $\mathrm{Mg}$ Speciation in Advanced $\mathrm{Mg}$ Battery Electrolyte Solutions. J. Am. Chem. Soc 2016, 138 (1), 328-337. [PubMed: 26636472]

14. Oscar T; Rana M; A. TS; Fuminori M; N. EG; S. YV, An Efficient Halogen - Free Electrolyte for Use in Rechargeable Magnesium Batteries. Angew. Chem. Int. Ed 2015, 54 (27), 7900-7904.

15. McArthur SG; Geng L; Guo J; Lavallo V, Cation reduction and comproportionation as novel strategies to produce high voltage, halide free, carborane based electrolytes for rechargeable $\mathrm{Mg}$ batteries. Inorg. Chem. Front 2015, 2 (12), 1101-1104.

16. Hahn NT; Seguin TJ; Lau K-C; Liao C; Ingram BJ; Persson KA; Zavadil KR, Enhanced Stability of the Carba-closo-dodecaborate Anion for High-Voltage Battery Electrolytes through Rational Design. J. Am. Chem. Soc 2018, 140 (35), 11076-11084. [PubMed: 30059211]

17. Herb JT; Nist-Lund CA; Arnold CB, A Fluorinated Alkoxyaluminate Electrolyte for MagnesiumIon Batteries. ACS Energy Lett 2016, 1 (6), 1227-1232.

18. Zhao-Karger Z; Gil Bardaji ME; Fuhr O; Fichtner M, A new class of non-corrosive, highly efficient electrolytes for rechargeable magnesium batteries. J. Mater. Chem. A 2017, 5 (22), $10815-10820$.

19. Zhonghua Z; Zili C; Lixin Q; Jing G; Huimin X; Xiaogang W; Pu H; Huiping D; Shizhen L; Xinhong Z; Shanmu D; Zhihong L; Guanglei C; Liquan C, Novel Design Concepts of Efficient $\mathrm{Mg}$ - Ion Electrolytes toward High - Performance Magnesium-Selenium and Magnesium-Sulfur Batteries. Adv. Energy Mater 2017, 7 (11), 1602055.

20. Luo YR, Comprehensive Handbook of Chemical Bond Energies Comprehensive Handbook of Chemical Bond Energies, CRC Press, Boca Raton, FL, 2007. 
(A)

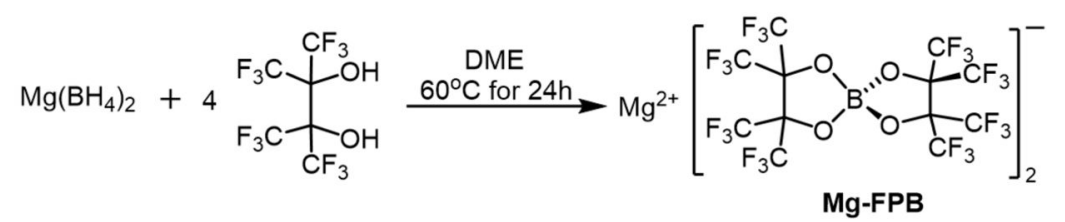

(D)

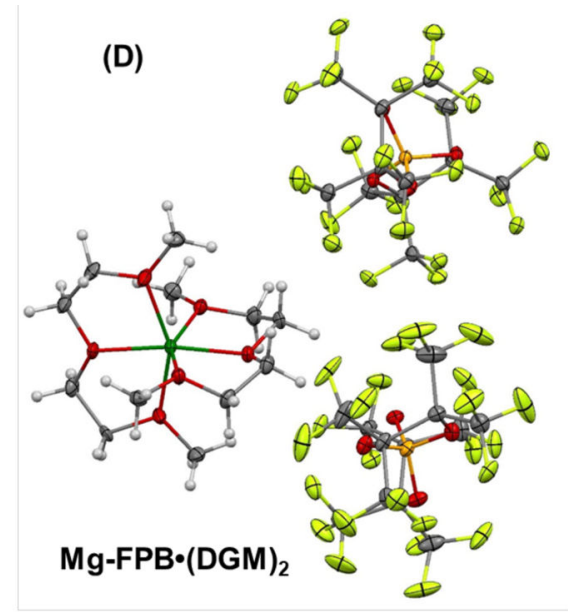

(B)

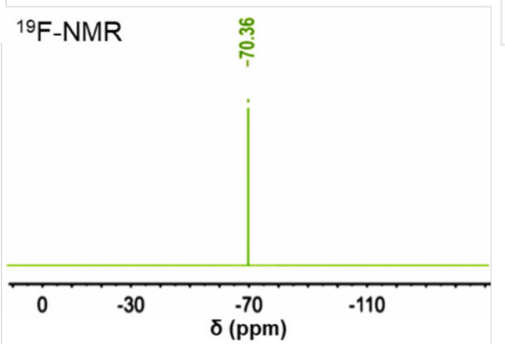

(C)

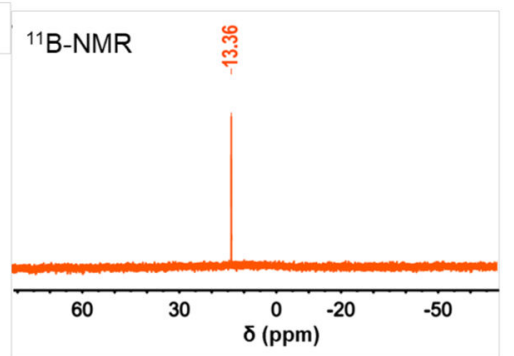

Figure 1.

(A) Synthesis of Mg-FPB. (B) and (C) ${ }^{19} \mathrm{~F}$ and ${ }^{11} \mathrm{~B}-\mathrm{NMR}$ spectrums of Mg-FPB in MeCN$d_{3 .}$. (D) X-ray single crystal structure of DGM solvated Mg-FPB. Mg, green; O, red; C, gray; $\mathrm{H}$, white; $\mathrm{B}$, orange; $\mathrm{F}$, green yellow. 

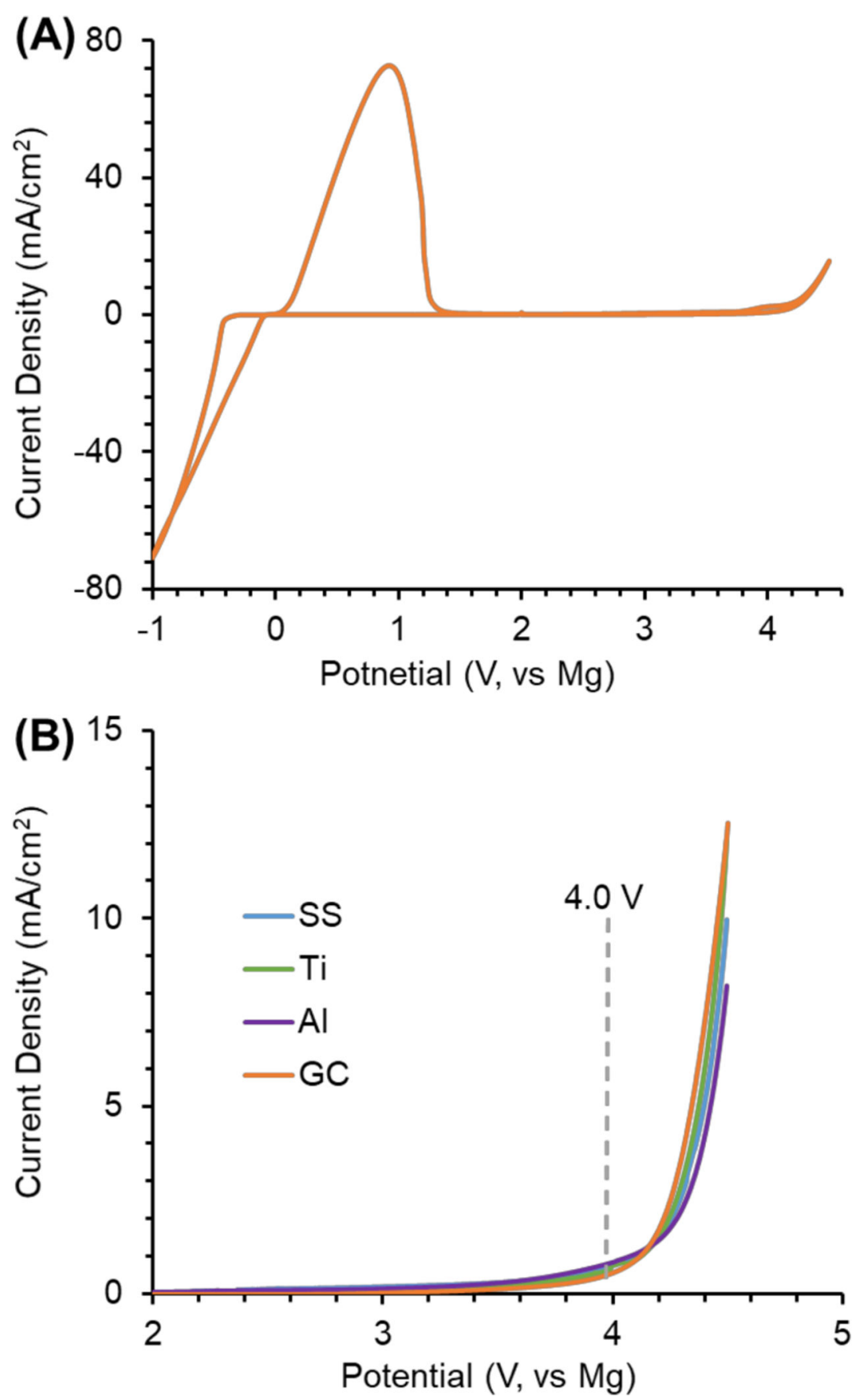

Figure 2.

(A) CV curves of $0.5 \mathrm{M} \mathrm{Mg-FPB} \mathrm{electrolyte} \mathrm{in} \mathrm{DGM} \mathrm{on} \mathrm{glassy} \mathrm{carbon} \mathrm{working} \mathrm{electrode.}$ (B) LSV curves of different working electrodes shown the anodic stability of the Mg-FPB electrolyte in DGM: stainless steel (SS, blue), Ti (green), Al (purple), glassy carbon (GC, orange). Condition: $\mathrm{Mg}$ as reference and counter electrode, $50 \mathrm{mV} / \mathrm{s}$ scan rate. 

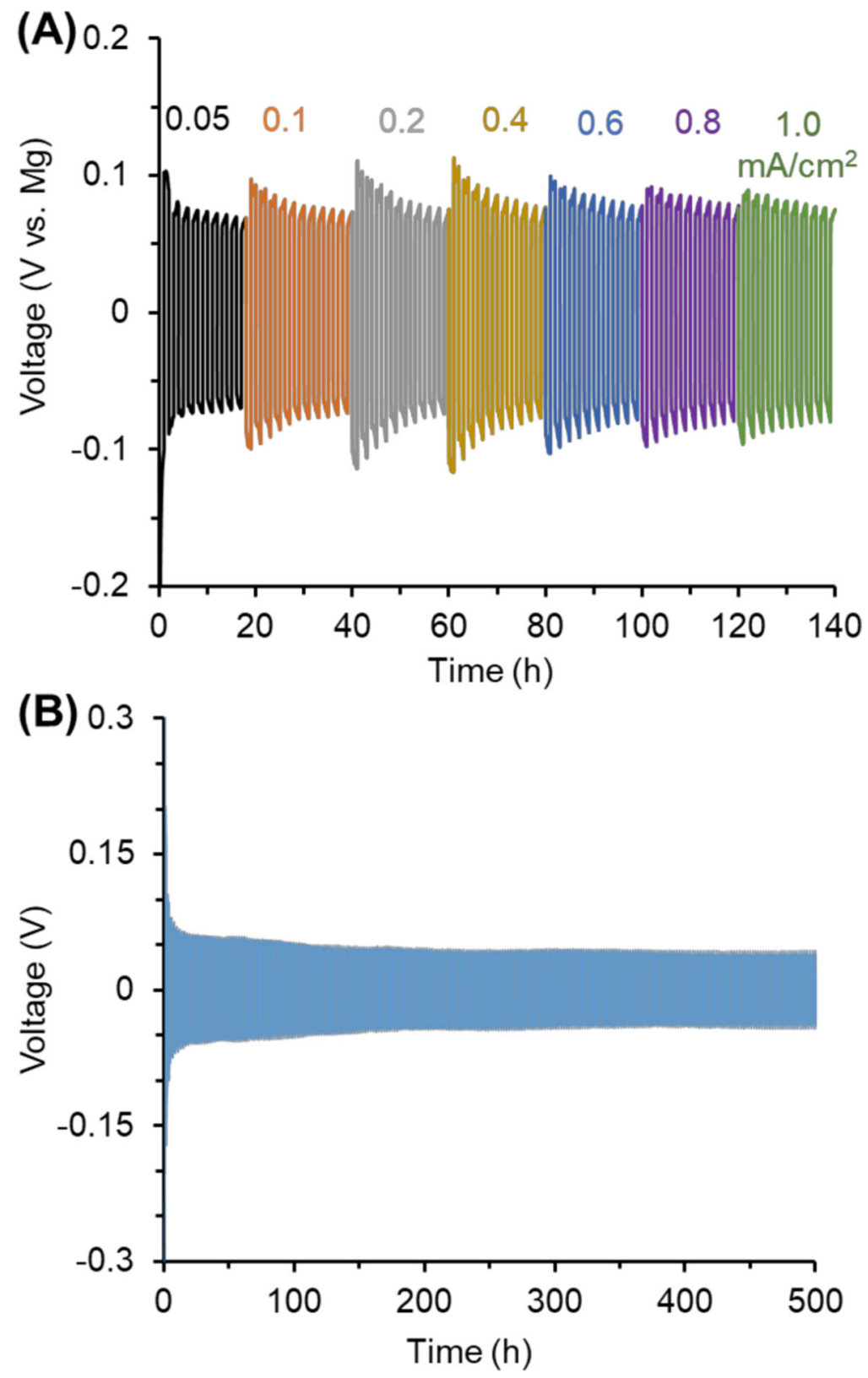

Figure 3.

(A) Mg metal plating/stripping from an $\mathrm{Mg}|0.5 \mathrm{M} \mathrm{Mg-FPB}| \mathrm{Mg}$ symmetric cell tested at current density from $50 \mu \mathrm{A} / \mathrm{cm}^{2}$ to $1.0 \mathrm{~mA} / \mathrm{cm}^{2}$. (B) Galvanostatic cycling performance of $\mathrm{Mg} \mid 0.5 \mathrm{M}$ Mg-FPB $\mid \mathrm{Mg}$ symmetric cell at $0.1 \mathrm{~mA} / \mathrm{cm}^{2}$. 


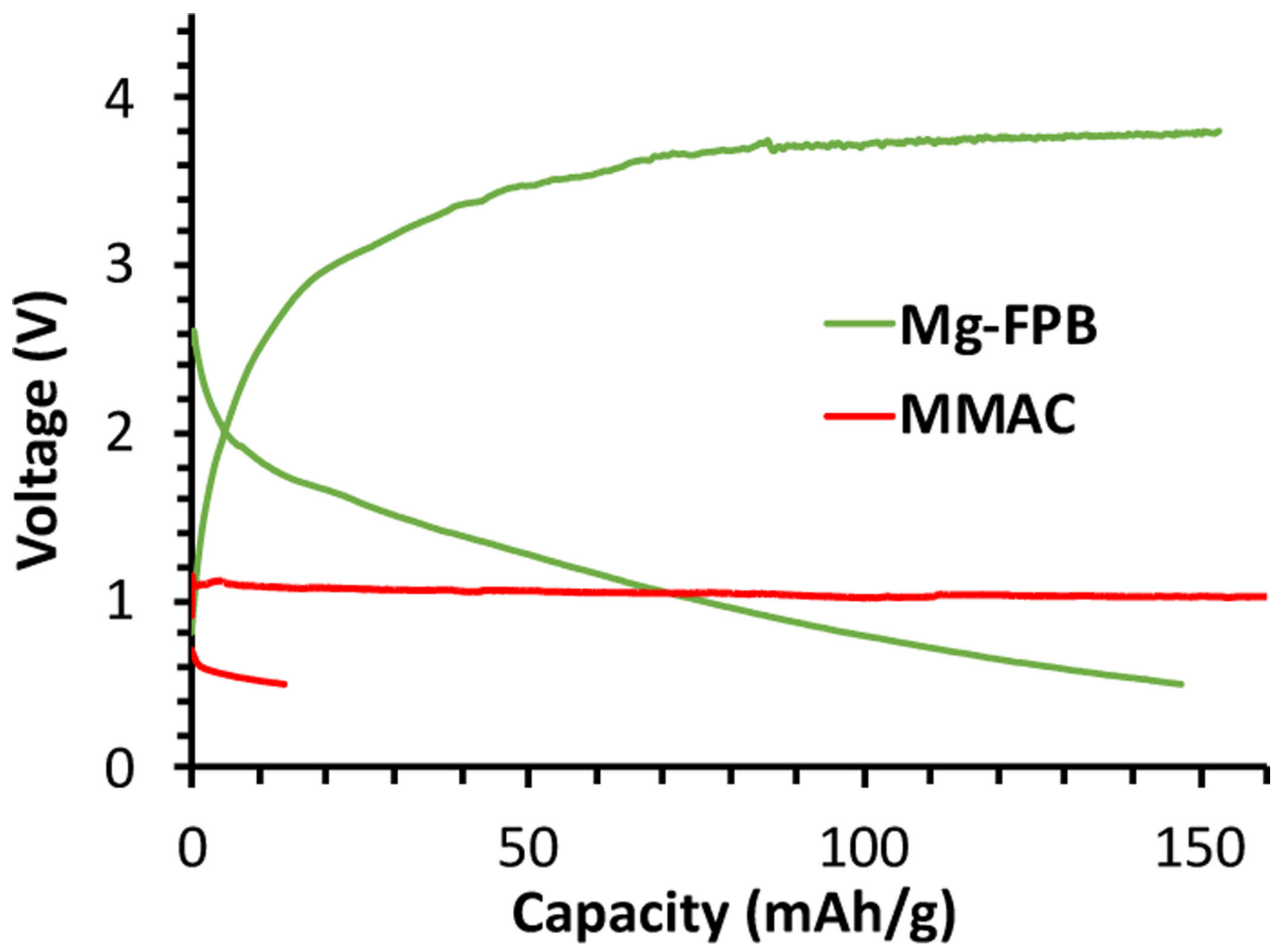

Figure 4.

The representative charge/discharge curves of $\mathrm{Mg}-\mathrm{MnO}_{2}$ battery using $0.5 \mathrm{M} \mathrm{Mg-FPB}$ electrolyte in DGM at $10 \mu \mathrm{A} / \mathrm{g}$ current density. 

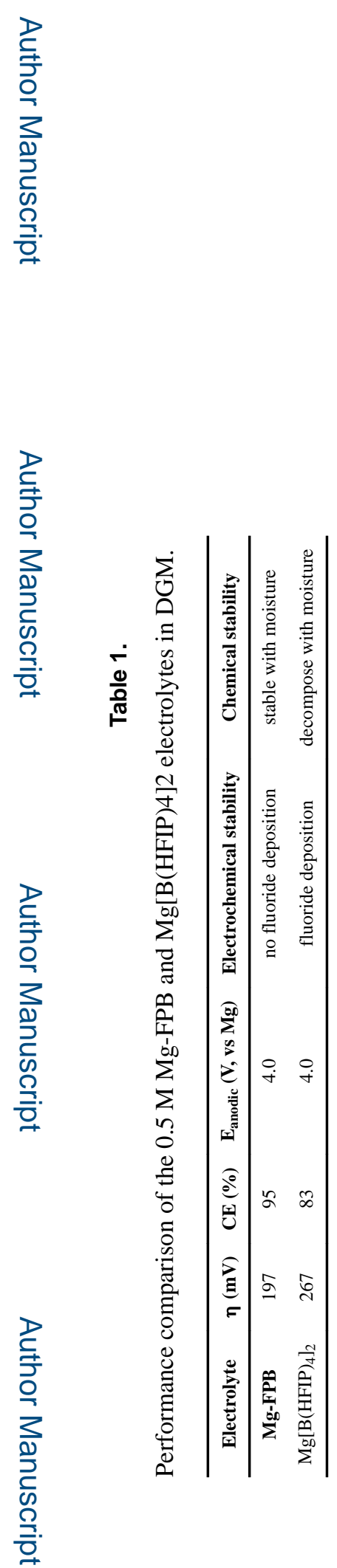

Angew Chem Int Ed Engl. Author manuscript; available in PMC 2019 August 19. 